\title{
Macroeconomics Effects on Project Finance Performances and Sustainability
}

\author{
Francesco Campanella ${ }^{1}$, Luana Serino ${ }^{1}$, Teresa Nelli ${ }^{1}$, Domenico Graziano ${ }^{1}$ \\ ${ }^{1}$ Department of Economics, University of Campania “Luigi Vanvitelli”, Capua (CE), Italy \\ Correspondence: Francesco Campanella, University of Campania “Luigi Vanvitelli”, Capua (CE), Italy
}

Received: April 11, 2018

Accepted: April 29, 2018

Online Published: May 9, 2018

doi:10.5539/ibr.v11n6p21

URL: https://doi.org/10.5539/ibr.v11n6p21

\begin{abstract}
The aim of this study is to demonstrate whether the macroeconomic variables have a significant impact on profitability, sustainability, and value creation of projects implemented with the project financing technique. The empirical analysis was developed using the performance trend from 1997 to 2014 (18 years) of 10 large infrastructure projects financed using the project financing technique in BRICS countries (Brazil, Russia, India, China, South Africa) and in PIIGS countries (Portugal, Italy, Ireland, Greece, Spain). The results show that the indicators of economic performance and financial sustainability are influenced by various macroeconomic variables. Instead, value creation indicators are affected little by exogenous factors. In the operative sense, our work suggests that in the design phase of an infrastructure it is necessary to consider that macroeconomic factors can positively or negatively impact economic and financial performance.
\end{abstract}

Keywords: project finance, public-private partnership, BRICS, PIIGS, performance, sustainability

\section{Introduction}

Project finance has ancient origins, but in recent years has had numerous applications in the public-private partnership (PPP) for infrastructure sector. The return of this financing model is caused by the crisis in public budgets that has reduced the available financial resources.

The scarcity of resources has undermined entire economic systems, especially in those countries that have a high public debt that needs restructuring interventions. Therefore, while some high-growth countries with sustainable debts, called BRICS (Brazil, Russia, India, China, South Africa), suffered less from the effects of the economic crisis on structural investments, others, called PIIGS (Portugal, Italy, Ireland, Greece, Spain), added to the effects of the crisis and a high public debt that has contracted public investments.

The aim of this research is to highlight the effects of macroeconomic imbalances on the economic and financial performance of investments in infrastructures financed through project financing. In fact, the project financing technique could be inefficient if used without considering the negative influence of macroeconomic imbalances in the relative countries. Therefore, in our research we have selected a sample composed of BRICS and PIIGS countries that have invested in large infrastructures using the project financing technique from 1997 to 2014.

Starting from these hypotheses and methods, the contribution of our work is to highlight the existence of a link between macroeconomic variables and profitability, sustainability, and the creation of project finance value.

Beyond the introduction, this paper is organized into four additional sections. The second section, the literature review, describes the main topic of PPP. The third section describes the sample and methods and the fourth describes the results. In the fifth section the discussion and conclusions of the empirical research are shown.

\section{Literature Review}

During the past two decades, an important new method of large-scale financing, called project financing, has took place in Europe.

Starting from the most accredited definition, belonging to Nevitt (2000:1), project financing is "a financing operation of a particular economic unit, in which a lender considers, from the initial state, the cash flow of the economic unit in question, as the source of funds that will allow repayment of the loan and the activities of the economic unit as collateral for the loan".

Project financing, or project finance, is a form of financing through which public administrations can use private 
capital for the realization of projects and infrastructures for community use.

Kensinger and Martin (1988) present several advantages of a project realized through a PPP, as its own flexibility allows the project to increase "above and beyond the possible structural rigidity of the legal environment to which it has to be adapted" (Gatti, 2013, p. 234). Among the comparative advantages, the most important is the reduction of information costs and tax liabilities. In addition to these advantages, the project financing technique makes it possible to ensure that the operational and financial risks of the project carried out using this technique do not affect the company's existing activities. In project financing, the project is managed by a separate company that is owned by a project sponsor.

The agreement between public administration and the private company can take place through the establishment of a project company (also called SPV or Special Purpose Vehicle), which is owned by a project sponsor, that usually takes an active role in the realization and/or management of the project itself. The realization of the project takes place through the preparation of a series of contracts with multiple parties, including the host government, the project's customers and suppliers, and the banking system that typically provides most of the debt financing. This contractual organization allows for the reduction of agency problems and the allocation of specific project risks to those parties best able to manage them is realized (Brealey, Cooper, \& Habib, 1996).

As a consequence, the risks inherent in each economic operation are maintained, for each of the subjects involved, within acceptable levels of tolerability. This formula emphasizes the crucial role of resources complementarity in the formation of partnerships (Dinica, 2008).

The main difference between conventional financing and project financing is that the economic-financial returns of the project are mixed with those of the other existing projects, but in project financing a project is evaluated solely on the basis of its ability to generate consistent cash flows (Shah \& Thankor, 1987).

Traditional financing instruments use loans to finance all of the economic activity of the financed company in general, in project financing the loan is aimed toward the realization of a certain work or activity on the basis that the economic return of such work depends on final remuneration of the lender. For this reason, in project financing it is fundamental to find a trade-off between the needs of public administration compared to the needs of the community, the needs of sustainability, and financial profitability of the investment.

Return on Investment (ROI) is used to measure the profitability of a project, that is the capacity of invested capital to generate economic returns. To evaluate the feasibility of a project, that consists of the verification of the economic convenience of the developer to promote investment, indexes such as the Net Present Value (NPV) and the Internal Rate Return (IRR) are used. However, one of the characteristic elements of project financing is the high use of leverage by the vehicle company. For this reason, the objective is to ensure that the vehicle company is able to repay the debt contracted and remunerate capital invested $(\mathrm{Gatti}, 2008)$ through the project's operating cash flows generated during the period in which the work is said to be hot, which is fully operational. To this end, to monitor the vehicle company's ability to repay the debt, and therefore consequently the financial sustainability of the project, that is the ability to generate sufficient cash flows to guarantee the repayment of activated loans, bankability indexes are used. In this way, the financial soundness of the project is highlighted (Falini, 2008).

For assessing the bankability of a project, realized through PPP, different indices can be calculated. The Debt Service Coverage Ratio (DSCR) is calculated because it represents the capability of the project to repay the debt service in each time period of the life of the project. In fact, in each period of time the DSCR is given by the ratio between the cash flow generated by the project and the debt repayment in the same period. The Loan Life Cover Ratio (LLCR), given by the annual report between the NPV project and the amount of debt, evaluates the SPV ability to repay an outstanding loan. The Project Life Cover Ratio is like the previous. It is obtained from the relationship between DSCR and the LLCR. In general, a project realized through the project financing formula should mitigate risk through a high degree of bankability, high debt leverage, and low level of equity capital (De Marco et al., 2016)

The practice of project financing as a financing technique has very distant origins. In Texas in the 1920s, specific contractual structures were used to mitigate the risks associated with the research and exploitation of oil fields (John \& John, 1991).

During the 1920s, this practice became widely used in the United States in the energy sector, as this sector has different potential environmental and safety risks, which must be opportunely managed (Razavi, 1996).

Since the 1980s, project financing has established itself as an infrastructure financing technique to compensate for the limitation of the public funds available which exists in many countries (Grimsey \& Lewis, 2002). Therefore, during the nineteenth century, increasing attention addressed the potential role of private financing 
through public-private partnerships (Eichengreen, 1995; Estache, Serebrisky, \& Wren-Lewis, 2015).

About the relation between public and private subjects, a PPP is defined broadly as "a cooperative arrangement between the public and private sectors that involves the sharing of resources, risks, responsibilities, and rewards with others for the achievement of joint objectives" (Kwak, Chih \& Ibbs, 2009, p. 52).

In addition, project financing can be seen as a driver of the economic growth process, both in developed economies and in low-income countries (Kleimeier \& Versteeg, 2010). PPPs used for infrastructure services allow for the increase of value for money by providing more efficient and reliable services (Kwak et al., 2009; Nisar, 2007). For this reason, PPPs have emerged as a contractual strategy of funding infrastructure in BRIC as well as in PIIG countries.

According to World Bank's Private Participation in Infrastructure (PPI) database, in a period of two decades (1990-2010) the BRIC are the top four countries in terms of number of infrastructure projects realized through private participation. In fact, this number, about 3000 , is approximately $50 \%$ of the total global projects (Kateja, 2012). However, in terms of investment, Russia lags behind the other three emerging markets, but the growth is mainly driven by China (Mwase \& Yang, 2012).

In 2010, South Africa joined the group of four emerging powers, which changed its name to BRICS. The South African PPPs experience started recently. Indeed, in the late 1990s, the South African government set a framework which allows the recourse to PPPs, creating a dedicated PPP unit to increase the confidence of potential private partners. However, projects in PPP have been mainly realized in telecommunication, little progress has been made in the infrastructure sector (Akintoye \& Beck, 2009).

About the PPPs experience in PIIGS countries, Portugal has been positively demonstrating its effect in rapidly developing infrastructure service and in improving their quality in terms of reliability (Monteiro, 2005). Portugal has intensively used the project financing formula to build most of the highway network. This network has increased by $700 \%$ between 1990 and 2007 and similar improvements have been made in Ireland, which recorded an increase of $900 \%$, and in Greece with a reported increase in the highway network of 500\% (Sarmento \& Renneboog, 2015).

In Italy, Ireland, Greece, and Spain different PPPs in the infrastructure sector have been realized, but these countries suffer from legislative and enforcement deficiencies.

In this context, Grimsey \& Lewis (2005) gave important information about projects made through project financing method in Italy, Ireland and Greece.

In Italy, the Merloni Bill ${ }^{1}$ (enactment in 1994) set the framework to regulate the use of private capital in public works nd in 1999 a PPP task force was established. However, the use of new projects in the form of project financing is extremely discouraged because of the administrative complexity and legislative ambiguity that exists in this field.

In Ireland, major new road developments are now undertaken and funded through the project financing technique, like the M4 PPP Toll Motorway Projects which was signed in March 2003 and is the first Irish road PPP from Kinnegad to Kilcock.

In Greece, there are legal problems to be resolved, but different PPP projects have been realized and completed, such as the Spata Airport and the Athens ring road.

Regarding Spain, the situation is more serious because it is characterized by an absence of a regulatory framework and laws that do not cover concessions. However, in recent years private financing, through a PPP, of new infrastructures is growing (Benito, Montesinos, \& Bastida, 2008).

In general, the principal reason that justifies the adoption of PPPs, both in BRICSs and in PIIGS countries, is that it allows for the resolution, at least partially, of the deficit of physical infrastructures of the countries, involving private participations in the projects.

Our work contributes to the existing literature, filling an empirical lack, by establishing a relationship between macroeconomic variables and the profitability and financial sustainability of the projects implemented through PPP. In fact, although there is a stream of literature that found the link between macroeconomic variables and classical project performance (Aizenman \& Marion, 1993; Denizer, Kaufmann, \& Kraay, 2013; Ghura \& Goodwin, 2000; Kaufmann \& Wang,1995; Kilby, 2000; Mlambo \& Oshikoya, 2001; Schiantarelli \& Sembenelli,

\footnotetext{
${ }^{1}$ Since 1994, the Merloni Law has been amended several times to reach a better regulation for project financing in the infrastructure sector.
} 
1997), there is a lack regarding the influence of projects realized through PPP.

The aim of this study is to demonstrate whether the macroeconomic variables have a significant impact on profitability, sustainability, and value creation of projects implemented with the project financing technique.

\section{Sample and Methods}

The empirical analysis was developed using the performance trend from 1997 to 2014 (18 years) of 10 large infrastructure projects financed using the project financing technique.

In particular, five projects have been developed in the BRICS countries and five have been developed in the PIIGS countries. In total, the sample consists of 180 observations.

The values of the variables were quantified according to the information derived from Thomson Reuters (Eikon and Datastream) and the financial statements of the SPV.

The analysis was performed using the panel data regression model and adopting a random effects model.

Regarding the methodological point of view, the demonstration of the research hypothesis was carried out by adopting the following model:

$\left(\right.$ ROI $_{1997-2014} ;$ LLCR $_{1997-2014} ;$ NPV $_{1997-2014} ;$ IRR $\left._{1997-2014}\right)=f($ Brics_Piigs; Deficit_gdp; Inflation; Monetary;

Trade_surplus; Delta_gdp; Tax_benefits; Rating; Banking_Outlook)

Where the dependent variables are:

$\mathrm{ROI}_{1997-2014}=\frac{E B I T}{\text { Total asset }}$. This variable is the indicator of profitability of the project. It is an index that expresses the profitability of the total financial resources employed in the business activity, therefore it indicates if the assets are used efficiently

$\mathrm{LLCR}_{1997-2014}=\frac{\sum_{t=s}^{S+n} \frac{\text { Cash }_{\left(10 w^{t}\right.}{ }^{t}+\text { Debt Reserve }}{\text { Outstanding }}}{\text { Out }}$. This variable is the indicator of bankability during the period of debt existence. This indicator measures the project's ability to repay the debt contracted through operating cash flows.

$N P V_{1997-2014}=\sum_{t=0}^{n} \frac{\text { Cash Flow }_{t}}{(1+W A C C)^{t}}$. This variable is the present value of expected cash flows using the opportunity cost of capital. While ROI measures project performance, the net present value measures the value created by the project for shareholders. Furthermore, ROI is influenced by accounting measures while the NPV refers to market measures.

$I R R_{1997-2014}=\sum_{t=0}^{n} \frac{\text { Cash Flow }_{t}}{(1+I R R)^{t}}=0$. This variable makes the NPV of all cash flows from a particular project equal to zero. The selection of investment projects using the IRR method is simpler than the NPV method. However, the IRR method has limitations that can make the investment choice wrong.

The independent variables are:

Brics_Piigs. This variable has a value of 1 if the country in which the project financing investment was made is BRICS. If the country is a PIIGS, the variable has a value of 0 . This variable is a proxy of the influence of a country's economic development with respect to the investment in the infrastructure.

Deficit_gdp $=\frac{\text { Deficit }}{\text { Gross Domestic Product }}$. This variable is a proxy for the financial solidity of a country and its potential for development. This variable is a dummy variable that has the value of 1 if it exceeds the $3 \%$ threshold, otherwise the value is 0 . In our research, this threshold is established using the Maastricht Treaty or the Treaty on European Union.

Inflation. This variable is a proxy of consumers' purchasing capacity. According to ISTAT definition, inflation is measured through the construction of a consumer price index, a statistical tool that measures the variations over 
time of the prices of a basket of goods and services, which represents the actual household consumption in a specific year.

Monetary. This variable is a dummy variable that has a value of 1 if the country is using an expansive monetary policy, otherwise the value is 0 . The proxy of the expansive monetary policy is the reduction of interest rates in the years from 1997 to 2014.

Trade_surplus. This is a variable that measures the development potential derived from the international trade of a country. In our research this variable is a dummy variable that has a value of 1 if the trade surplus exceeds $6 \%$, otherwise the value is 0 . In our research, this threshold is established using the European Union Macroeconomic Imbalance Procedure.

Delta_gdp $=\frac{G D P_{t}}{G D P_{t-1}}-1$. This variable measures the annual growth rate of the Gross Domestic Product (GDP).

This variable is a proxy of the economic development rate of a country.

Tax_benefits. This variable is a dummy variable that has a value of 1 if the country has a tax law favorable to investments financed using the project financing technique, otherwise the value is 0 .

Rating variable refers to the country's debt rating. Specifically, the country rating is that of Standard and Poor's Global Ratings. This alphabetic variable was converted into a numeric variable (AAA = 1; D = 10).

Banking_Outlook. This variable is a judgment expressed by Standard and Poor's Global Ratings on the future stability of a country's banking system. This variable is a dummy variable that has a value of 1 if the outlook is positive, otherwise the value is 0 .

\section{Results}

Before commenting on the regression analysis and answering the hypothesis of research, it is necessary to make some considerations regarding the correlation analysis between the variables distributed normally using the Pearson indices correlation matrix (Table 1).

Table 1 shows that many variables in the period 1997-2014 are significantly correlated, but often Pearson's indices are low.

Table 1. Pearson correlations for variables from 1997 - 2014

\begin{tabular}{|c|c|c|c|c|c|c|c|c|c|c|c|c|c|}
\hline & ROI & LLCR & NPV & IRR & $\begin{array}{c}\text { Brics_ }_{-} \\
\text {Piigs } \\
\end{array}$ & $\begin{array}{c}\text { Deficit/ } \\
\text { gdp }\end{array}$ & Inflation & Monetary & $\begin{array}{c}\text { Trade } \\
\text { surplus }\end{array}$ & $\begin{array}{c}\text { Delta_ } \\
\text { PIL }\end{array}$ & $\begin{array}{c}\text { Tax_- } \\
\text { benefits }\end{array}$ & Rating & $\begin{array}{l}\text { Banking } \\
\text { Outlook }\end{array}$ \\
\hline ROI & 1 & & & & & & & & & & & & \\
\hline LLCR & $0.335^{* * *}$ & 1 & & & & & & & & & & & \\
\hline NPV & $0.502^{* * *}$ & $0.193^{* * *}$ & 1 & & & & & & & & & & \\
\hline IRR & 0.023 & 0.062 & -0.033 & 1 & & & & & & & & & \\
\hline $\begin{array}{c}\text { Brics_ } \\
\text { Piigs }\end{array}$ & -0.034 & -0.016 & -0.022 & $-0.720^{* * *}$ & 1 & & & & & & & & \\
\hline $\begin{array}{c}\text { Deficit/ } \\
\text { gdp }\end{array}$ & $-0.132 *$ & -0.056 & $-0.137 *$ & 0.018 & 0.067 & 1 & & & & & & & \\
\hline Inflation & 0.052 & 0.009 & 0.047 & -0.008 & -0.008 & -0.026 & 1 & & & & & & \\
\hline Monetary & $0.182^{* * *}$ & $0.245^{* * *}$ & $0.153^{* *}$ & 0.076 & $-0.138^{*}$ & -0.018 & 0.026 & 1 & & & & & \\
\hline $\begin{array}{c}\text { Trade } \\
\text { surplus }\end{array}$ & 0.022 & 0.055 & -0.105 & -0.076 & 0.044 & 0.045 & -0.086 & 0.069 & 1 & & & & \\
\hline $\begin{array}{c}\text { Delta_ } \\
\text { PIL }\end{array}$ & 0.077 & -0.044 & 0.044 & $0.151^{* *}$ & $-0.209^{* *}$ & $-0.149^{* *}$ & 0.050 & 0.103 & $-0.158^{* *}$ & 1 & & & \\
\hline $\begin{array}{c}\text { Tax_- } \\
\text { benefits }\end{array}$ & $0.852^{* * * *}$ & $0.266^{* * *}$ & $0.417^{* * *}$ & -0.027 & 0.011 & -0.061 & 0.067 & $0.198^{* * * *}$ & -0.011 & 0.120 & 1 & & \\
\hline Rating & -0.025 & -0.015 & -0.002 & $-0.540^{* * *}$ & $0.759^{* * *}$ & 0.082 & 0.065 & -0.052 & -0.113 & -0.020 & 0.044 & 1 & \\
\hline $\begin{array}{l}\text { Banking } \\
\text { Outlook }\end{array}$ & $0.289^{* * *}$ & $0.843^{* * * *}$ & $0.143^{* *}$ & 0.023 & 0.000 & 0.036 & -0.030 & $0.195^{* * *}$ & -0.045 & 0.013 & $0.316^{* * *}$ & 0.030 & 1 \\
\hline
\end{tabular}

$* * *$ Correlation is significant at the 0.01 level

**Correlation is significant at the 0.05 level

*Correlation is significant at the 0.10 level 
To investigate the cause-effect relationship between the variables under investigation and provide responses to the research hypotheses, GLS analysis was performed (Table 2).

First, we calculated both the fixed effects and random effects to decide which are the best solution using the Hausman Test. The results suggest the development of random effects because, unlike the fixed effects model, the variation across entities is assumed to be random and uncorrelated with the predictor or independent variables included in the model. In addition, random effects assume that the entity's error term is not correlated with the predictors, which allows for time-invariant variables to play a role as explanatory variables.

With respect to the research hypothesis, the results show that:

Regarding $R O I_{1997-2014}$ the variable Deficit_GDP is negatively correlated with the ROI index. On the other hand, the variable Tax_benefits positively influences the economic performances of the project

Table 2. Panel data regression - Random effects (coefficients and z-value)

\begin{tabular}{|c|c|c|c|c|}
\hline PANEL & $\mathrm{ROI}_{1997-2014}$ & LLCR $_{1997-2014}$ & $\mathrm{NPV}_{1997-2014}$ & $\mathrm{IRR}_{1997-2014}$ \\
\hline (Constant) & $0.313(7.90)^{* * * *}$ & $0.266(6.56)^{3+3.1}$ & $0.483(7.07)^{* * * *}$ & $0.461(8.73)^{3 * * *}$ \\
\hline Brics_Piigs & $-0.006(-0.16)$ & $0.002(0.04)$ & $0.004(0.06)$ & $-0.400(-8.26)^{* * * *}$ \\
\hline Deficit/GDP & $-0.047(-2.10)^{* *}$ & $-0.055(-2.41)^{* *}$ & $-0.062(-1.60)$ & $0.037(1.24)$ \\
\hline Inflation & $0.001(0.03)$ & $0.043(1.07)$ & $0.009(0.14)$ & $-0.013(0.24)$ \\
\hline Monetary & $0.004(0.16)$ & $0.048(1.96)^{* *}$ & $0.048(1.16)$ & $-0.012(-0.39)$ \\
\hline Trade surplus & $0.014(0.61)$ & $0.047(1.99)^{* *}$ & $-0.061(-1.55)$ & $-0.025(-0.80)$ \\
\hline$\triangle P I L$ & $-0.040(-0.89)$ & $-0.072(-1.55)$ & $-0.049(-0.63)$ & $0.008(0.13)$ \\
\hline Tax benefits & $0.474(19.96)^{* * * *}$ & $-0.008(-0.34)$ & $0.221(5.39)^{* * *}$ & $-0.011(-0.36)$ \\
\hline Rating & $-0.003(-0.73)$ & $-0.002(-0.38)$ & $-0.002(-0.22)$ & $-0.000(-0.04)$ \\
\hline Banking Outlook & $0.016(0.66)$ & $0.486(20.01)^{* * * *}$ & $0.001(0.03)$ & $0.016(0.52)$ \\
\hline Adj $R^{2}$ & 0.74 & 0.73 & 0.21 & 0.01 \\
\hline Wald chi ${ }^{2}$ & $480.65^{* * * *}$ & $479.59^{* * * *}$ & $43.63 * * *$ & $188.70^{* * * *}$ \\
\hline
\end{tabular}

$* * *$ Correlation is significant at the 0.01 level

**Correlation is significant at the 0.05 level

*Correlation is significant at the 0.10 level

About $L L C R_{1997-2014}$, the variable deficit_GDP is negatively correlated with the LLCR index. On the other hand, the variables Monetary, Trade_surplus, and banking outlook positively influence the bankability index.

Concerning $N P V_{1997-2014}$, the variable Tax_benefits positively influence $N P V$ project. Referring to $I R R_{1997-2014}$, the variable Brics_Piigs is negatively correlated with IRR.

In general, the results show that the indicators of economic performance (ROI) and financial sustainability (LLCR) are influenced by various macroeconomic variables. Instead, value creation indicators (NPV and IRR) are affected little by exogenous factors.

\section{Discussion and Conclusion}

With respect to the research hypothesis, we have found that some macroeconomic variables influence profitability (ROI), sustainability (LLCR), and value creation (NPV and IRR) of projects financed through project finance. Therefore, the research hypothesis is partially confirmed. In fact, not all of the variables selected in this research influence the performance of project finance.

In particular, the results show that the financial and economic sustainability of project finance is more influenced by macroeconomic variables than profitability and value creation. In fact, four variables are significant with respect to the bankability of the project. We also found that the balance of the state budget is relevant to the bankability of the project. Furthermore, sustainability is positively influenced by expansive monetary policies (i.e. quantitative easing), by the surplus of the trade balance, and by a positive judgement from rating agencies concerning the soundness of the country's banking system.

In order of relevance, profitability is the second variable most influenced by macroeconomic indicators. Particularly, the balance of the state budget influences the profitability of the project. Furthermore, we have observed that a tax policy favorable to project financing has a positive effect on the economic performance of the same.

Finally, the creation of value generated by project finance, measured by NPV and IRR, is the variable less influenced by macroeconomic factors. In fact, only a favorable tax policy seems to be relevant compared to NPV. Instead, a country belonging to the BRICS group or PIIGS influences IRR. The scarce influence of the macroeconomic variables confirms a limitation of capital budgeting techniques. In fact, these evaluation 
techniques do not consider the potential influence of the macroeconomic context on the project. In conclusion, we found that external factors have an influence on infrastructure project financing. This is the important contribution of our empirical work.

Overall, this research has significant implications in the operative sense. Indeed, based on our findings, our work suggests that in the design phase of an infrastructure it is necessary to consider that macroeconomic factors can positively or negatively affect economic and financial performance.

In other subsequent studies it would be appropriate to deepen this research in other geographical contexts. For example, it would be appropriate to study the effects of macroeconomic variables on project finance in countries such as Africa, where some factors such as corruption can also negatively impact investment performance.

\section{References}

Aizenman, J., \& Marion, N. P. (1993). Macroeconomic uncertainty and private investment. Economics Letters, 4l(2), 207-210. https://doi.org/10.1016/0165-1765(93)90198-L

Akintoye, A., \& Beck, M. (Eds.). (2009). Policy, management and finance of public-private partnerships. West Sussex, UK: John Wiley \& Sons.

Benito, B., Montesinos, V., \& Bastida, F. (2008). An example of creative accounting in public sector: The private financing of infrastructures in Spain. Critical Perspectives on Accounting, 19(7), 963-986. https://doi.org/10.1016/j.cpa.2007.08.002

Brealey, R. A., Cooper, I. A., \& Habib, M. A. (1996). Using project finance to fund infrastructure investments. Journal of Applied Corporate Finance, 9(3), 25-38. https://doi.org/10.1111/j.1745-6622.1996.tb00296.x

De Marco, A., Mangano, G., Michelucci, F. V., \& Zenezini, G. (2016). Using the private finance initiative for energy efficiency projects at the urban scale. International Journal of Energy Sector Management, 10(1), 99-117. https://doi.org/10.1108/IJESM-12-2014-0005

Denizer, C., Kaufmann, D., \& Kraay, A. (2013). Good countries or good projects? Macro and micro correlates of World Bank project performance. Journal of Development Economics, 105, 288-302. https://doi.org/10.1016/j.jdeveco.2013.06.003

Dinica, V. (2008). Initiating a sustained diffusion of wind power: the role of public-private partnerships in Spain. Energy Policy, 36(9), 3562-3571. https://doi.org/10.1016/j.enpol.2008.06.008

Eichengreen, B. (1995). Financing infrastructure in developing countries: lessons from the railway age. The World Bank Research Observer, 10(1), 75-91. https://doi.org/10.1093/wbro/10.1.75

Estache, A., Serebrisky, T., \& Wren-Lewis, L. (2015). Financing infrastructure in developing countries. Oxford Review of Economic Policy, 31(3-4), 279-304. https://doi.org/10.1093/oxrep/grv037

Falini, A. (2008). Il Project Financing. Vincoli e opportunità nel settore sanitario: Vincoli e opportunità nel settore sanitario. Milan, Italy: Franco Angeli.

Gatti, S. (2008). Project finance in theory and practice: designing, structuring, and financing private and public projects (2nd ed.). Burlington, MA: Academic Press.

Gatti, S. (2013). Project finance in theory and practice: designing, structuring, and financing private and public projects. Burlington, MA: Academic Press.

Ghura, D., \& Goodwin, B. (2000). Determinants of private investment: a cross-regional empirical investigation. Applied Economics, 32(14), 1819-1829. https://doi.org/10.1080/000368400425044

Grimsey, D., \& Lewis, M. K. (2002). Evaluating the risks of public private partnerships for infrastructure projects. International Journal of Project Management, 20(2), 107-118. https://doi.org/10.1016/S0263-7863(00)00040-5

Grimsey, D., \& Lewis, M. K. (2005). Are public private partnerships value for money? Evaluating alternative approaches and comparing academic and practitioner views. Accounting Forum, 29(4), 345-378. https://doi.org/10.1016/j.accfor.2005.01.001

John, T. A., \& John, K. (1991). Optimality of project financing: Theory and empirical implications in finance and accounting. Review of Quantitative Finance and Accounting, 1(1), 51-74. https://doi.org/10.1007/BF02408406

Kateja, A. (2012). Building infrastructure: Private participation in emerging economies. Procedia-Social and Behavioral Sciences, 37, 368-378. https://doi.org/10.1016/j.sbspro.2012.03.302 
Kaufmann, D., \& Wang, Y. (1995). Macroeconomic policies and project performance in the social sectors: A model of human capital production and evidence from LDCs. World Development, 23(5), 751-765. https://doi.org/10.1016/0305-750X(95)00003-U

Kensinger, J. W., \& Martin, J. D. (1988). Project Finance: Raising Money The Old-Fashioned Way. Journal of Applied Corporate Finance, 1(3), 69-81. https://doi.org/10.1111/j.1745-6622.1988.tb00474.x

Kilby, C. (2000). Supervision and performance: the case of World Bank projects. Journal of Development Economics, 62(1), 233-259. https://doi.org/10.1016/S0304-3878(00)00082-1

Kleimeier, S., \& Versteeg, R. (2010). Project finance as a driver of economic growth in low-income countries. Review of Financial Economics, 19(2), 49-59. https://doi.org/10.1016/j.rfe.2010.01.002

Kwak, Y. H., Chih, Y., \& Ibbs, C. W. (2009). Towards a comprehensive understanding of public private partnerships for infrastructure development. California management review, 51(2), 51-78. https://doi.org/10.2307/41166480

Mlambo, K., \& Oshikoya, T. W. (2001). Macroeconomic factors and investment in Africa. Journal of African Economies, 10(2), 12-47. https://doi.org/10.1093/jae/10.Suppl2.12

Monteiro, R. S. (2005). Public-private partnerships: some lessons from Portugal. EIB Papers, 10(2), 73-81.

Mwase, N., \& Yang, Y. (2012). BRICs' philosophies for development financing and their implications for LICs (Working Paper). Retrived from https://www.imf.org/external/pubs/ft/wp/2012/wp1274.pdf

Nevitt, P. K. (2000). Project financing (7th ed.). London, UK: Euromoney Books.

Nisar, T. M. (2007). Value for money drivers in public private partnership schemes. International Journal of Public Sector Management, 20(2), 147-156. https://doi.org/10.1108/09513550710731508

Razavi, H. (1996). Financing oil and gas projects in developing countries. Finance and Development, 33, 2-5.

Sarmento, J. M., \& Renneboog, L. (2015). 16 Portugal's experience with Public Private Partnerships. In A. Akintoye, M. Beck, \& M. Kumaraswamy (Eds.), Public Private Partnerships: A Global Review (266-282). New York, NY: Routledge.

Schiantarelli, F., \& Sembenelli, A. (1997). The maturity structure of debt: Determinants and effects on firms' performance: Evidence from the United Kingdom and Italy (Working Paper No. 1699). Retrieved from https://papers.ssrn.com/sol3/papers.cfm?abstract_id=620623

Shah, S., \& Thakor, A. V. (1987). Optimal capital structure and project financing. Journal of Economic Theory, 42(2), 209-243. https://doi.org/10.1016/0022-0531(87)90086-X

\section{Copyrights}

Copyright for this article is retained by the author(s), with first publication rights granted to the journal.

This is an open-access article distributed under the terms and conditions of the Creative Commons Attribution license (http://creativecommons.org/licenses/by/4.0/). 